\title{
In Vitro Corrosion and Biological Assessment of Bioabsorbable WE43 Mg Alloy Specimens
}

\author{
Emmet Galvin $^{1}$ (D), Swarna Jaiswal ${ }^{2, *}$ (D), Caitríona Lally ${ }^{3}$ (D), Bryan MacDonald ${ }^{1}$ \\ and Brendan Duffy ${ }^{2}$ \\ 1 School of Mechanical and Manufacturing Engineering, Dublin City University, Dublin 9, Ireland; \\ emmet.galvin3@mail.dcu.ie (E.G.); bryan.macdonald@dcu.ie (B.M.) \\ 2 Centre for Research in Engineering and Surface Technology, FOCAS Institute, Dublin Institute of Technology, \\ Kevin Street, Dublin 8, Ireland; brendan.duffy@dit.ie \\ 3 Trinity Centre for Bioengineering, Trinity Biomedical Sciences Institute, and Department of Mechanical and \\ Manufacturing Engineering, School of Engineering, Trinity College Dublin, the University of Dublin, \\ Dublin 2, Ireland; lallyca@tcd.ie \\ * Correspondence: swarna.jaiswal@dit.ie; Tel.: +353-1-402-7948
}

Received: 28 July 2017; Accepted: 29 August 2017; Published: 5 September 2017

\begin{abstract}
Bioabsorbable magnesium (Mg) alloys have several advantages in biomedical implant applications as they reduce certain risks associated with conventional permanent implants. However, limited information is available for WE43 Mg alloy specimens with comparable size to that of biomedical implants such as cardiovascular stents and orthopaedic wires. The present work examines the corrosion and biological properties of WE43 stent precursor tubes and wire specimens suited for orthopaedic implants. The corrosion-induced loss of mechanical integrity as well as the corrosion-induced changes in surface morphology of the specimens are elucidated and compared. Cell viability assays were performed with human umbilical vein endothelial cells (HUVECs). It was observed that Mg ions released from the WE43 alloy acted as a growth stimulator of HUVECs.
\end{abstract}

Keywords: bioabsorbable; biocompatible; magnesium

\section{Introduction}

$\mathrm{Mg}$ and its alloys have emerged as a new class of biomaterials for use in bioabsorbable medical devices such as stents [1,2] and orthopaedic implants [3]. When compared to traditional metallic biomaterials like 316L, biodegradable Mg-based devices can eliminate the need for a second surgical procedure for implant removal which reduces cost and patient morbidity [4]. Further, Mg alloys exhibit numerous favourable physical characteristics such as lower density, higher specific strength, and an elastic modulus closer to that of human bone [5].

While a number of studies have examined the mechanical properties of bulk WE43 specimens [6-9], these often have different materials processing histories to medical devices, and the presence of scale-effects means that the mechanical behaviour may not capture the true device behavior [9]. Thus, it is important that material characterisation testing for small-scale medical devices is conducted on the device itself or on a sample of the device material in the final or finished form. However, few studies have been published that examine the in vitro corrosion performance of WE43 stent precursor tubes and stents [10-13] and WE43 wires suited for use as orthopaedic implants [14-16]. While some data relating to the performance of WE43 dog-bone specimens was presented in our previous study [12], the main aim of this study is to compare and contrast the in vitro corrosion and biological performance of WE43 specimens prepared from stent precursor tubes and wires. 


\section{Materials and Methods}

\subsection{Preparation of Specimens and Mechanical Testing}

A total of 27 dog-bone and 18 wire specimens having the geometry and dimensions shown in Figure 1 were laser cut from stent precursor tubes and cleaved from wires of the WE43 Mg alloy, respectively, which contained approximately $93 \% \mathrm{Mg}$, 4\% yttrium (Y), 2.3\% neodymium (Nd), $0.7 \%$ zirconium $(\mathrm{Zr})$, and the remainder of rare-earth (RE) elements, as measured by inductively coupled plasma mass spectrometry (7500 ICP-MS, Agilent Technologies, Santa Clara, CA, USA). Metallographic analysis confirmed that dog-bone and wire specimens had comparable average grain sizes of 10 to $15 \mu \mathrm{m}$ following mechanical processing and T6 heat treatment. All specimens were finished by phosphoric acid etching and reactive ion etching surface treatments, as described in earlier work [17] and had an average surface roughness of $0.17 \mu \mathrm{m}$, as measured by an atomic force microscope (Nano-RTM O-020, Pacific Nanotechnology, Santa Clara, CA, USA). Finished dog-bone specimens had an outer diameter (OD) of $2.09 \mathrm{~mm}$, wall thickness of $0.14 \mathrm{~mm}$, and a strut width of $0.12 \mathrm{~mm}$ while wire specimens had an OD of $2 \mathrm{~mm}$ and length of $10 \mathrm{~mm}$, as measured by a scanning electron microscope (Leo 440 Stereoscan, Leica Cambridge Ltd., Cambridge, UK). Control specimens with the same dimensions as the Mg specimens were manufactured from 316L stainless steel tubes and wires. The tab regions on each specimen were coated with an epoxy resin to limit corrosion to the test region.

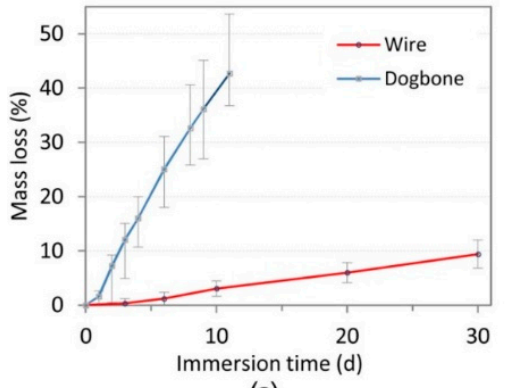

(a)

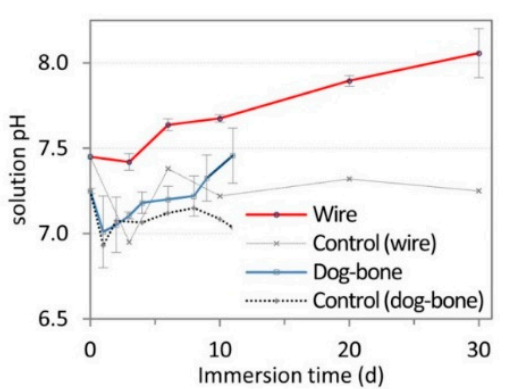

(b)

Figure 1. Plot of (a) percentage mass lost over time for dog-bone and wire specimens (b) evolution of SBF solution $\mathrm{pH}$. Error bars represent $95 \%$ confidence intervals derived from T-table $(\mathrm{n}=3)$.

Mechanical testing on dog-bone samples has already been published in an earlier study [12]. Wire specimens were also tested using a similar protocol, whereby mechanical strength testing was performed to determine the corrosion-induced loss of mechanical integrity of the specimens over time. Uniaxial tensile testing was carried out to failure in one loading cycle using a materials testing machine (Z005, Zwick Roell, Ulm, Germany) with a 5-kN load cell. A preload of $0.5 \mathrm{~N}$ and a crosshead speed of $1 \mathrm{~mm} / \mathrm{min}$ were used. Tests were terminated when the load dropped below $70 \%$ of the maximum load value. Local strain at the specimen gauge portion was recorded using a video extensometer (Messphysik, Fürstenfeld, Austria) and the compliance of the load frame was derived and then removed from all subsequent stress-strain data (derived from crosshead travel) by way of post-processing in MS Excel. The conversion of elongation to engineering strain was based on a $10 \mathrm{~mm}$ and $20 \mathrm{~mm}$ gauge length for dog bone and wires specimens, respectively.

Specimen stresses were calculated based on the original specimen cross section and so the change in cross section due to necking and corrosion was not accounted for; this approach has been used previously in similar studies [18]. Engineering stress-strain curves were produced for each specimen. The elastic modulus (E), $0.005 \%$ offset yield strength $\left(\sigma_{\mathrm{y}}\right)$ and ultimate tensile strength (UTS), strain at $\operatorname{UTS}\left(\varepsilon_{\mathrm{u}}\right)$, and the ultimate strain at failure $\left(\varepsilon_{\mathrm{f}}\right)$ were calculated in accordance with ASTM E111-04. 


\subsection{Immersion Testing}

The corrosion behaviour of the dog-bone and wire specimens was characterised through immersion experiments performed in simulated body fluid (SBF). The main purpose of the corrosion experiments was to determine the specimen corrosion rate and the influence of this corrosion on specimen mechanical integrity and surface morphology over time. Before corrosion testing, specimens were stored in a desiccator for $24 \mathrm{~h}$ and sterilised by exposure to ultraviolet irradiation. Specimens were placed in a separate container and exposed to Hank's balanced salt solution (H8264, Sigma Aldrich, Arklow, Ireland) on all surfaces of the test region. The ratio of solution volume (mL) to exposed specimen surface area $\left(\mathrm{cm}^{2}\right)$ was approximately 62.5 and 30.6 for dog bone and wire specimens, respectively; well above the minimum ratio recommended for $\mathrm{Mg}$ alloys [19]. Corrosion testing was performed under sterile conditions in an incubator (Nuaire NU-5500E, $37 \pm 2{ }^{\circ} \mathrm{C}, 5 \% \mathrm{CO}_{2}$ ) where the $\mathrm{pH}$ of the SBF was measured (HI-98127, Hanna Instruments, Woonsocket, RI, USA) and maintained within a physiological range (6.5-7.9). Specimens were removed at various intervals of time, cleaned in a $10 \%$ chromic acid solution (27081 Sigma Aldrich, St. Louis, MO, USA) at $55{ }^{\circ} \mathrm{C}$ in order to remove corrosion products, and weighed using a mass balance with a resolution of $0.00001 \mathrm{~g}$ (Sartorius RC210P, Gottingen, Germany). Corrosion surfaces were imaged using a SEM.

Furthermore, the quantification of $\mathrm{Mg}$ ion release from specimens (wire) was determined using inductively coupled plasma atomic emission spectrometry (ICP-AES), (Varian Liberty 150, Agilent Technologies Inc., Palo Alto, CA, USA) with the instrument optimised at $279.553 \mathrm{~nm}$ wavelength on aqueous solutions. The specimens were incubated in $10 \mathrm{~mL}$ cell culture medium (medium 200, without supplements) for $72 \mathrm{~h}$ in a humidified atmosphere $\left(5 \% \mathrm{CO}_{2}, 95 \%\right.$ air at $37^{\circ}$ tem) [20]. The samples were acidified in $10 \% \mathrm{HNO}_{3}$ before measuring by ICP.

\subsection{Cell Viability}

The biocompatibility of the specimen (wire) was evaluated using human umbilical vein endothelial cells (HUVECs, Bioscience, Shannon, Ireland). HUVECs were maintained in medium 200 (M200 PRF, Bioscience) supplemented with Low Serum Growth Supplement (LSGS, Bioscience) at $37^{\circ} \mathrm{C}$ in a humidified atmosphere of $5 \% \mathrm{CO}_{2}$.

The indirect cell viability MTT (3-(4,5-dimethylthiazol-2-yl)-2,5-diphenyltetrazolium bromide) assay was employed [21,22]. In brief, Mg alloys were kept in the cell culture medium for $72 \mathrm{~h}$, which gives an extraction medium containing $103.3 \mathrm{ppm} \mathrm{Mg}^{2+}$ ion (measured by ICP). Both sides of specimens were exposed to UV radiation for $2 \mathrm{~h}$ before extraction of the medium containing magnesium ions. The extracted medium was diluted to $10 \%$ concentration using medium M200 with supplements (Low Serum Growth Supplement) in preparation for the cell viability assays. HUVECs were seeded onto 96-well cell culture plates at $5 \times 10^{3}$ cells per $100 \mathrm{~mL}$ medium in each well and incubated overnight in order to ensure attachment to the well. The medium in each well was replaced with $100 \mathrm{~mL}$ of $\mathrm{Mg}$ extract with supplements (Low Serum Growth Supplement) and incubated in a humidified atmosphere with $5 \% \mathrm{CO}_{2}$ at $37^{\circ} \mathrm{C}$ for $1,3,5$, and 7 days [23]. The culture medium with $10 \% \mathrm{DMSO}$, with and without extracted medium, were considered the positive and negative controls, respectively. After incubation the cells were treated with MTT dye and the absorbance was measured using a Synergy multi-mode micro-plate reader at a wavelength of $570 \mathrm{~nm}$.

\section{Results}

\subsection{Mechanical Testing}

Based on the results of the immersion tests the mass lost over time by the dog-bone and wire specimens is shown in Figure 1a. It can be seen that both specimen types exhibited a relatively low rate of corrosion for the first 1 to 2 days immersion; however, it increased thereafter to give a steady average corrosion rate of $0.021 \mathrm{mg} \cdot \mathrm{cm}^{-2} \cdot \mathrm{h}^{-1}$ and $0.011 \mathrm{mg} \cdot \mathrm{cm}^{-2} \cdot \mathrm{h}^{-1}$ for dog-bone and wire specimens, respectively. The corrosion test for the dog-bone specimens was terminated at 11 days as 
the majority of specimen mechanical integrity had been lost, corresponding to a mass loss of about $40 \%$. The corrosion test for the wire specimens was terminated at 30 days as the corrosion-induced loss of mechanical integrity of the specimens was high, despite a relatively small mass loss of $9.4 \%$.

The solution $\mathrm{pH}$ for specimens was maintained within physiological levels for the duration of the corrosion tests, as shown in Figure 1b. Compared to the $\mathrm{pH}$ of the stainless steel 316L control specimens, the increase in $\mathrm{pH}$ observed for WE43 may be attributed to specimen corrosion resulting in the release of $\mathrm{Mg}$ into the SBF.

Representative stress-strain curves are shown in Figure 2 for (a) dog-bone and (b) wire specimens, respectively. For both specimen types, specimen strength and failure strain decreased significantly with immersion time. It can be observed that the corrosion-induced loss of mechanical integrity was very advanced after 11 days and 30 days for dog-bone and wire specimens, respectively. Further, the yield stress and UTS for both specimen types dimished significantly over time, as shown in Figure 3. The greatest reduction in yield stress and UTS was observed for the dog-bone specimens, as shown in Figure 3a.

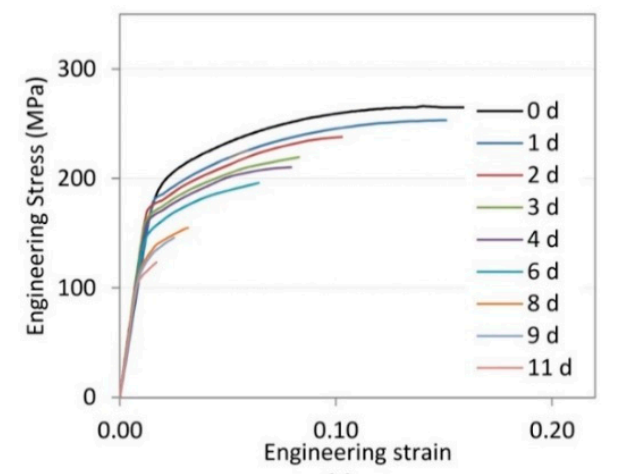

(a)

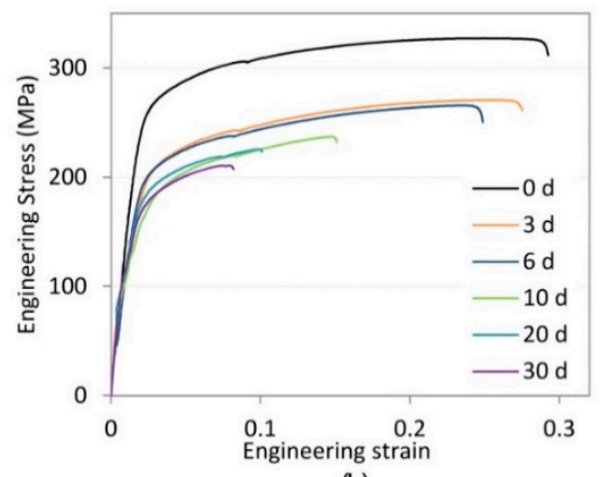

(b)

Figure 2. Representative stress-strain curves for (a) dog-bone and (b) wire specimens over time. Error bars omitted for clarity $(n=3)$.

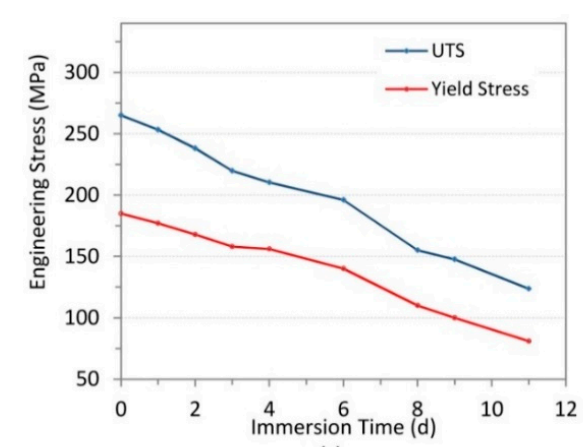

(a)

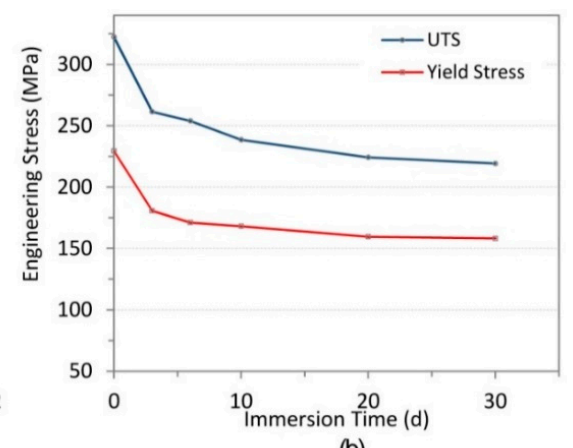

(b)

Figure 3. Mechanical properties (UTS and yield stress) of (a) dog-bone and (b) wire specimens over time. Error bars omitted for clarity $(n=3)$.

\subsection{Surface Morphology Studies}

Representative SEM images, displaying typical surfaces on dog-bone and wire specimens are shown in Figures 4 and 5, respectively. A significant change in the morphology of the surface layer was observed owing to the formation of pit-like corrosion features on dog-bone specimens (Figure 4b) and wire specimens (Figure $5 \mathrm{~b}, \mathrm{c}$ ) after 2 days and 3 to 6 days, respectively. For both specimen types the corrosion attack advanced across large regions of the surface, in a layer-by-layer manner, thus a relatively uniform specimen morphology resulted after 6 days and 20 days immersion for dog-bone 
(Figure 4e) and wire specimens (Figure 5e), respectively. The layer of corrosion products that formed on the specimens (not shown here) was found to be typically composed of $\mathrm{Ca}, \mathrm{O}, \mathrm{P}, \mathrm{Mg}, \mathrm{Cl}$, and $\mathrm{C}$, as measured by an energy-dispersive X-ray spectrometer (INCA Energy 350 XT microanalysis system).

(a)

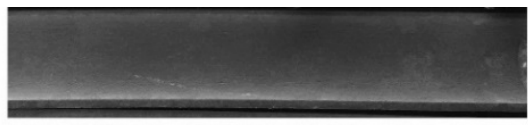

(b)

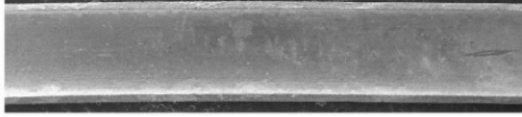

(c)

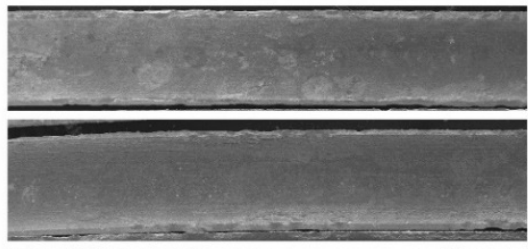

(e)

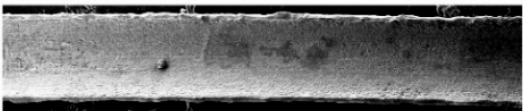

(f)

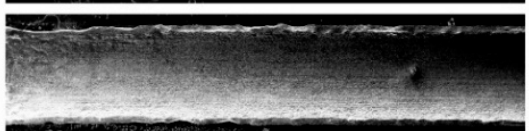

(g)

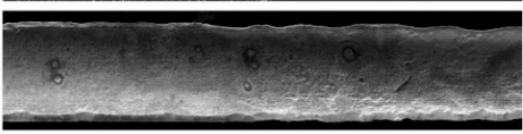

(h)

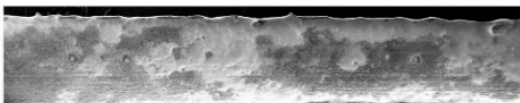

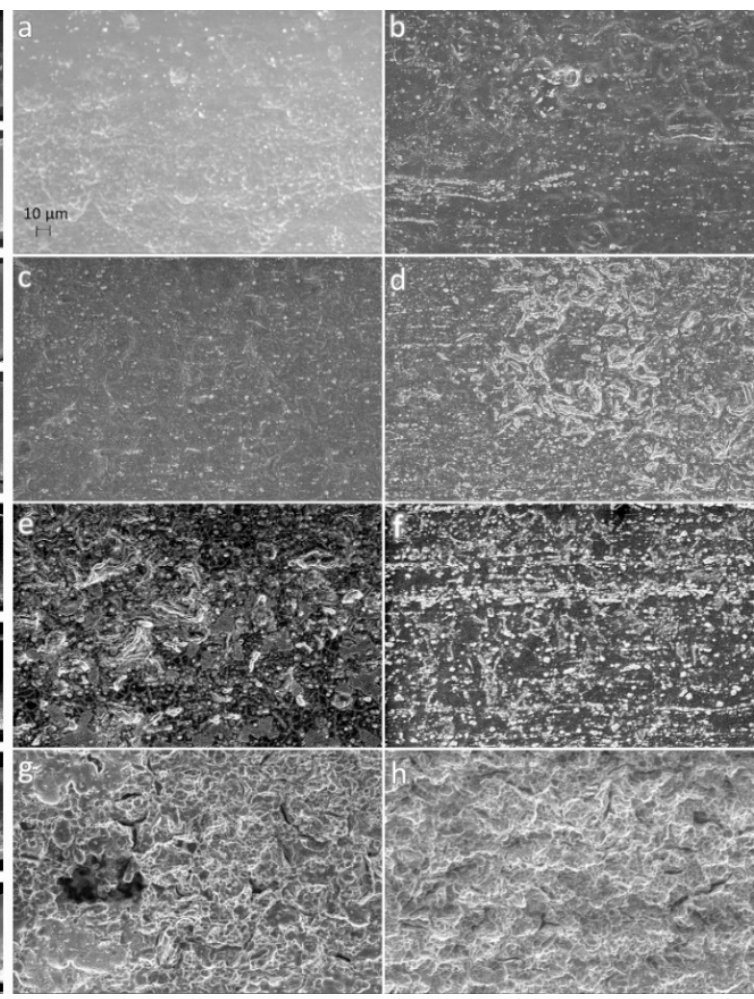

Figure 4. Typical morphology of dog bone specimens after immersion for (a) 1 day; (b) 2 days; (c) 3 d; (d) 4 days; (e) 6 days; (f) 8 days; (g) 9 days; and (h) 11 days. SEM Magnification: $30 \times$ (images on left) and $400 \times$ (images on right).

a

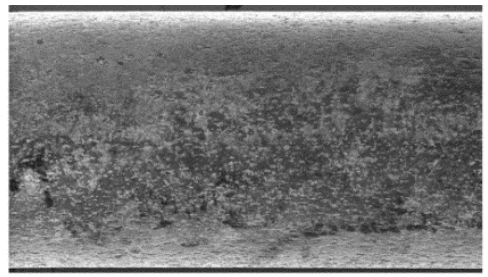

C

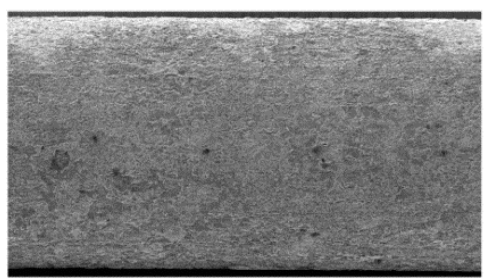

e

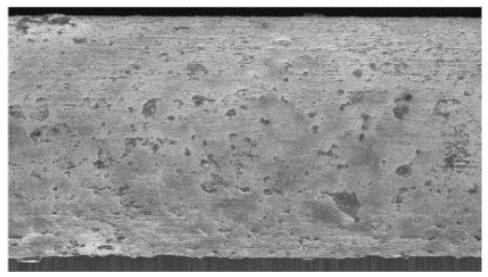

b

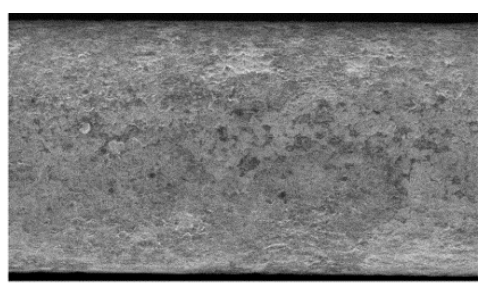

d

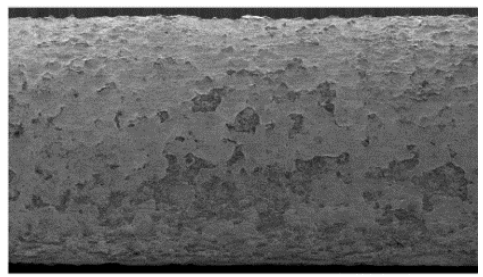

f

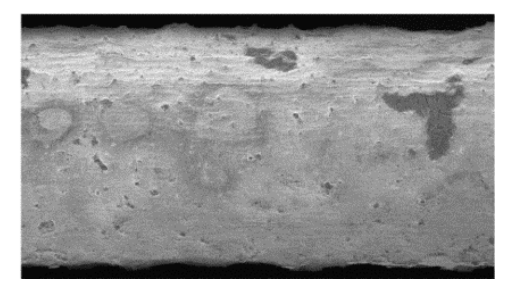

Figure 5. Typical morphology of wire specimens after immersion times of (a) 0 day; (b) 3 days; (c) 6 days; (d) 10 days; (e) 20 days; and (f) 30 d. (SEM Magnification: 400×). 


\subsection{Indirect Cytotoxicity Evaluation of $\mathrm{Mg}$ Ions on HUVECS}

The Mg WE43 implant materials are intended for use in various bio-implants ranging from fracture fixation to cardiovascular applications. In this study, the cytotoxicity of an $\mathrm{Mg}$ specimen (wire) was examined using a MTT assay evaluating the proliferation and viability of the HUVECs (commonly used to evaluate stent materials) in contact with $\mathrm{Mg}$ ions extracted from alloys (Figure 6). It was observed that the cell viability of HUVECs increased with the increasing exposure time in the presence of $\mathrm{Mg}$ extracts (103.3 ppm), which indicates that the extracted cations promoted healthy growth of the cells. The cell viability of extracts was higher than $85 \%$ on days 3,5 , and 7 as compared to less than $40 \%$ in the DMSO control.

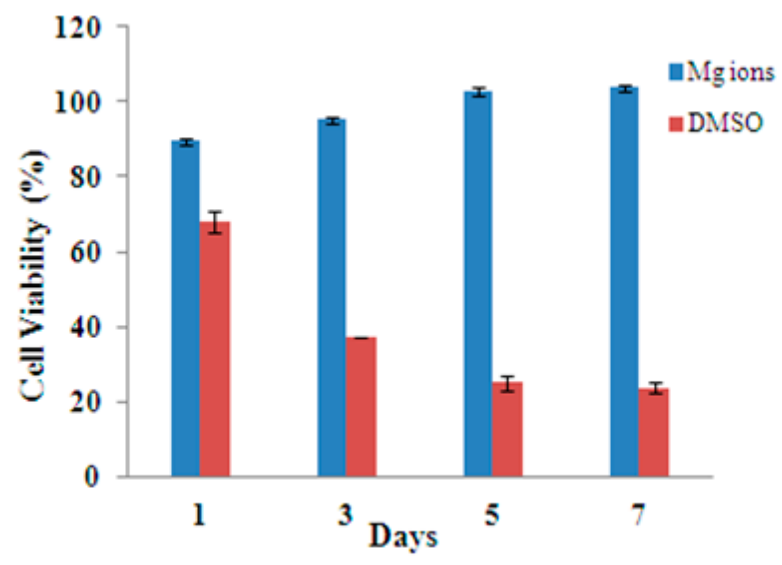

Figure 6. Effect of Mg ions (103.3 ppm) on the HUVECs examined by MTT assay after 1, 3, 5, and 7 days of exposure.

\section{Discussion}

The relatively high corrosion rates of $\mathrm{Mg}$ alloys observed in vivo and in SBF, may generally be attributed to the inability of $\mathrm{Mg}$ surfaces to naturally passivate in aqueous chloride-containing solutions at physiological $\mathrm{pH}$ levels and the influence of other aggressive ions such as phosphates, sulphates, and carbonates [24]. Mg alloys are susceptible to corrosion owing to galvanic activity among their primary constituents namely, primary $\alpha$, eutectic $\alpha$, and $\beta$-phases. Corrosion attack often involves galvanic coupling between anodic and cathodic areas that result in preferential dissolution of the (anodic) Mg matrix ( $\alpha$-phase), leading to undermining and fallout of the secondary phase particles, and cathodic reduction of water [25]. A relatively uniform galvanic corrosion attack was observed in this study (Figures 4 and 5). Small pits initiated on the affected surface and spread laterally over the whole surface but tended not to form deep pits owing to the self-limiting nature of localised corrosion in $\mathrm{Mg}$, as observed in a previous study [26]. The steady-state corrosion rates $\left(0.021 \mathrm{mg} \cdot \mathrm{cm}^{-2} \cdot \mathrm{h}^{-1}\right.$ and $0.011 \mathrm{mg} \cdot \mathrm{cm}^{-2} \cdot \mathrm{h}^{-1}$ ) measured in this work (Figure 1) correspond to corrosion rates of $0.99 \mathrm{~mm} /$ year and $0.52 \mathrm{~mm} /$ year for dog-bone and wire specimens, respectively. These corrosion rates are comparable with those previously reported for $\mathrm{Mg}$ alloys in vitro [27]. It is interesting to note that the corrosion rate of the dog-bone specimens $(0.99 \mathrm{~mm} /$ year $)$ was found to be approximately 1.9 times greater than that of the wire specimens $(0.52 \mathrm{~mm} /$ year). As the composition and surface finishing of both specimens was very similar, the difference in corrosion rates may be attributed to differences in materials processing [28]. For example, variations in crystallographic orientation that result from different materials processing in magnesium alloys have a strong influence on surface processes such as corrosion, dissolution, and oxidation.

The corrosion-induced reduction in the stress-strain response (Figure 2) and mechanical properties (Figure 3) observed in the corrosion tests likely resulted from the reduction in specimen cross-section and the influence of stress concentrations in corroded regions, as reported in previous studies [17]. 
The corrosion-induced loss of mechanical integrity (yield stress and UTS) observed for dog-bone specimens (Figure 3a) was relatively linear over time and had progressed significantly by 11 days. For wire specimens (Figure 3b), a large loss of mechanical integrity was observed after 3 days beyond which the rate of loss was linear and significantly lower when compared to dog-bone specimens.

The cytotoxicity study shows increased cell viability overtime in the presence of the $\mathrm{Mg}$ alloy extract (Figure 6). The lower viability at the first day of exposure can be attributed to the high rate of corrosion in the initial stages of exposure. It could be concluded that $\mathrm{Mg}$ ions increase cell viability over longer exposure times (seven days). The result demonstrates that the Mg alloy extraction medium has a positive influence on the viability and proliferation of the HUVECs.

These results agree with the previous observation, where no inhibitory effect of alkali-heat-treated $\mathrm{Mg}\left(\mathrm{NaHCO}_{3}-\mathrm{MgCO}_{3}\right)$ was recorded on marrow cell growth [20]. It was observed that $\mathrm{Mg}-0.5 \mathrm{Sr}$ alloy increases HUVEC viability over a seven day period of exposure. It was also reported that abundant $\mathrm{Mg}$ ions released from the $\mathrm{Mg} / \mathrm{Ca}$ specimen to the culture medium can enhance the cell attachment and promote the proliferation and growth of the L-929 cells [29].

\section{Conclusions}

A relatively uniform corrosion attack was observed in this study when compared to previous studies involving bulk specimens and specimens prepared by surface treatments unsuited to medical device manufacture such as mechanical polishing using silicon carbide papers [14]. In this study, the corrosion rate for dog-bone specimens was shown to be approximately 1.9 times greater than that for wire specimens of the same material composition. The findings demonstrate the strong influence upon corrosion kinetics of materials processing, surface finishing, and corrosion environment and for $\mathrm{Mg}$ alloys. Furthermore, the cell viability result demonstrate that the Mg alloy extraction medium has a positive influence on the viability and proliferation of the HUVECs, and in particular, the presence of $\mathrm{Mg}$ ions increase cell viability over longer exposure times (seven days). This work provides some new insight into the mechanical properties, temporal corrosion performance, and biocompatibility of WE43 Mg alloy tubes and wires suited for use in the manufacture of bioabsorbable medical devices. The data presented could also help inform future computational models for the preclinical assessment of Mg implants.

Acknowledgments: The authors would like to acknowledge the provision of project funding by Science Foundation Ireland (SFI) through a TIDA feasibility study grant (11/TIDA/I1935).

Author Contributions: Emmet Galvin performed the experiments and prepared the manuscript. Swarna Jaiswal designed, performed the biological assessment, metallurgical assessment and prepared the manuscript, Swarna Jaiswal and Emmet Galvin analysed the data. Caitríona Lally supervised the related research work. Bryan MacDonald helped in the manuscript preparation. Brendan Duffy is a principal investigator of the project.

Conflicts of Interest: The authors declare no conflicts of interest.

\section{References}

1. Haude, M.; Erbel, R.; Erne, P.; Verheye, S.; Degen, H.; Böse, D.; Vermeersch, P.; Wijnbergen, I.; Weissman, N.; Prati, F.; et al. Safety and performance of the drug-eluting absorbable metal scaffold (DREAMS) in patients with de-novo coronary lesions: 12 month results of the prospective, multicentre, first-in-man BIOSOLVE-I trial. Lancet 2013, 381, 836-844. [CrossRef]

2. Erbel, R.; Di Mario, C.; Bartunek, J.; Bonnier, J.; de Bruyne, B.; Eberli, F.R.; Erne, P.; Haude, M.; Heublein, B.; Horrigan, M.; et al. Temporary scaffolding of coronary arteries with bioabsorbable magnesium stents: A prospective, non-randomised multicentre trial. Lancet 2007, 369, 1869-1875. [CrossRef]

3. Farraro, K.F.; Kim, K.E.; Woo, S.L.; Flowers, J.R.; McCullough, M.B. Revolutionizing orthopaedic biomaterials: The potential of biodegradable and bioresorbable magnesium-based materials for functional tissue engineering. J. Biomech. 2014, 47, 1979-1986. [CrossRef] [PubMed] 
4. Agarwal, S.; Curtin, J.; Duffy, B.; Jaiswal, S. Biodegradable magnesium alloys for orthopaedic applications: A review on corrosion, biocompatibility and surface modifications. Mater. Sci. Eng. C 2016, 68, 948-963. [CrossRef] [PubMed]

5. Zeng, R.; Dietzel, W.; Witte, F.; Hort, N.; Blawert, C. Progress and challenge for magnesium alloys as biomaterials. Adv. Eng. Mater. 2008, 10, B3-B14. [CrossRef]

6. Huan, Z.G.; Leeflang, M.A.; Zhou, J.; Fratila-Apachitei, L.E.; Duszczyk, J. In vitro degradation behavior and cytocompatibility of Mg-Zn-Zr alloys. J. Mater. Sci. Mater. Med. 2010, 21, 2623-2635. [CrossRef] [PubMed]

7. Chen, X.; Liu, L.; Liu, J.; Pan, F. Microstructure, electromagnetic shielding effectiveness and mechanical properties of Mg-Zn-Y-Zr alloys. Mater. Des. 2015, 65, 360-369. [CrossRef]

8. Connolley, T.; McHugh, P.E.; Bruzzi, M. A review of deformation and fatigue of metals at small size scales. Fatigue Fract. Eng. Mater. Struct. 2005, 28, 1119-1152. [CrossRef]

9. Maier, P.; Zimmermann, F.; Rinne, M.; Szakács, G.; Hort, N.; Vogt, C. Solid solution treatment on strength and corrosion of biodegradable Mg6Ag wires. Mater. Corros. 2017. [CrossRef]

10. Witte, F.; Hort, N.; Vogt, C.; Cohen, S.; Kainer, K.U.; Willumeit, R.; Feyerabend, F. Degradable biomaterials based on magnesium corrosion. Curr. Opin. Solid State Mater. Sci. 2008, 12, 63-72. [CrossRef]

11. Galvin, E.; O’Brien, D.; Cummins, C.; Mac Donald, B.J.; Lally, C. A strain-mediated corrosion model for bioabsorbable metallic stents. Acta Biomater. 2017, 55, 505-517. [CrossRef] [PubMed]

12. Galvin, E.; Cummins, C.; Yoshihara, S.; Mac Donald, B.J.; Lally, C. Plastic strains during stent deployment have a critical influence on the rate of corrosion in absorbable magnesium stents. Med. Biol. Eng. Comput. 2017, 55, 1261-1275. [CrossRef] [PubMed]

13. Griebel, A.; Schaffer, J. Cold-drawn ZM21 and WE43 wires exhibit exceptional strength and ductility. Eur. Cell. Mater. 2014, 28. [CrossRef]

14. Maier, P.; Szakács, G.; Wala, M.; Hort, N. Mechanical and Corrosive Properties of Two Magnesium Wires: Mg4Gd and Mg6Ag. In Magnesium Technology; Manuel, M.V., Singh, A., Alderman, M., Neelameggham, N.R., Eds.; Springer Science \& Business Media: Berlin, Germany, 2015; pp. 393-398.

15. Bai, J.; Yin, L.; Lu, Y.; Gan, Y.; Xue, F.; Chu, C.; Yan, J.; Yan, K.; Wan, X.; Tang, Z. Preparation, microstructure and degradation performance of biomedical magnesium alloy fine wires. Prog. Nat. Sci. Mater. Int. 2014, 24, 523-530. [CrossRef]

16. McCartney, W.T.; Galvin, E.; Cummins, C.; Lally, C.; MacDonald, B.J. Use of a biodegradable magnesium implant for osseous fixation in four cases. Int. J. Appl. Res. Vet. Med. 2015, 13, 171-174.

17. Galvin, E.; Morshed, M.M.; Cummins, C.; Daniels, S.; Lally, C.; MacDonald, B. Surface modification of absorbable magnesium stents by reactive ion etching. J. Plasma Chem. Process. 2013, 33, 1137-1152. [CrossRef]

18. Bowen, P.K.; Gelbaugh, J.A.; Mercier, P.J.; Goldman, J.; Drelich, J. Tensile testing as a novel method for quantitatively evaluating bioabsorbable material degradation. J. Biomed. Mater. Res. B 2012, 100, 2101-2113. [CrossRef] [PubMed]

19. Yang, L.; Zhang, E. Biocorrosion behavior of magnesium alloy in different simulated fluids for biomedical application. Mater. Sci. Eng. C 2009, 29, 1691-1696. [CrossRef]

20. Bornapour, M.; Muja, N.; Shum-Tim, D.; Cerruti, M.; Pekguleryuz, M. Biocompatibility and biodegradability of Mg-Sr alloys: The formation of Sr-substituted hydroxyapatite. Acta Biomater. 2013, 9, 5319-5330. [CrossRef] [PubMed]

21. Jaiswal, S.; Bhattacharya, K.; McHale, P.; Duffy, B. Dual effects of $\beta$-cyclodextrin-stabilised silver nanoparticles: Enhanced biofilm inhibition and reduced cytotoxicity. J. Mater. Sci. Mater. Med. 2015, 26, 1-10. [CrossRef] [PubMed]

22. Agarwal, S.; Morshed, M.; Labour, M.N.; Hoey, D.; Duffy, B.; Curtin, J.; Jaiswal, S. Enhanced corrosion protection and biocompatibility of a PLGA-silane coating on AZ31 Mg alloy for orthopaedic applications. RSC Adv. 2016, 6, 113871-113883. [CrossRef]

23. Gu, X.; Zheng, Y.; Zhong, S.; Xi, T.; Wang, J.; Wang, W. Corrosion of, and cellular responses to Mg-Zn-Ca bulk metallic glasses. Biomaterials 2010, 31, 1093-1103. [CrossRef] [PubMed]

24. Xin, Y.; Chu, P.K. Influence of Tris in simulated body fluid on degradation behavior of pure magnesium. Mater. Chem. Phys. 2010, 124, 33-35. [CrossRef]

25. Kalb, H.; Rzany, A.; Hensel, B. Impact of microgalvanic corrosion on the degradation morphology of WE43 and pure magnesium under exposure to simulated body fluid. Corros. Sci. 2012, 57, 122-130. [CrossRef] 
26. Song, G.; Atrens, A. Recent insights into the mechanism of magnesium corrosion and research suggestions. Adv. Eng. Mater. 2007, 9, 177-183. [CrossRef]

27. Zhang, X.; Yuan, G.; Mao, L.; Niu, J.; Ding, W. Biocorrosion properties of as-extruded Mg-Nd-Zn-Zr alloy compared with commercial AZ31 and WE43 alloys. Mater. Lett. 2012, 66, 209-211. [CrossRef]

28. Ge, Q.; Dellasega, D.; Demir, A.G.; Vedani, M. The processing of ultrafine-grained Mg tubes for biodegradable stents. Acta Biomater. 2013, 9, 8604-8610. [CrossRef] [PubMed]

29. Li, Z.; Gu, X.; Lou, S.; Zheng, Y. The development of binary Mg-Ca alloys for use as biodegradable materials within bone. Biomaterials 2008, 29, 1329-1344. [CrossRef] [PubMed]

(C) 2017 by the authors. Licensee MDPI, Basel, Switzerland. This article is an open access article distributed under the terms and conditions of the Creative Commons Attribution (CC BY) license (http:// creativecommons.org/licenses/by/4.0/). 